EDUTECH : Jurnal Inovasi Pendidikan Berbantuan Teknologi

Vol. 1 No. 3 November 2021, e-ISSN : 2797-0140 | p-ISSN : 2797-0590

\title{
PENINGKATAN MOTIVASI DAN HASIL BELAJAR SISWA MELALUI MODEL PEMBELAJARAN PROBLEM BASED LEARNING DENGAN MEDIA POWERPOINT
}

\author{
MUSYRIFAH ZIDNI BAROROH \\ MAN Batang \\ e-mail: zidnibaroroh@gmail.com
}

\begin{abstract}
ABSTRAK
Penelitian ini bertujuan untuk mengetahui peningkatan motivasi dan hasil belajar siswa kelas $\mathrm{X}$ MAN Batang. Penelitian ini merupakan Penelitian Tindakan Kelas. Subjek penelitian ini adalah siswa kelas X MAN Batang. Pengumpulan data menggunakan teknik dokumentasi, observasi, angket dan tes. Validitas data menggunakan teknik triangulasi sumber dan triangulasi teknik. Teknik analisa data melalui tiga tahap yaitu reduksi data, penyajian data dan penarikan kesimpulan. Hasil penelitian yang dilakukan adalah 1). Motivasi belajar siswa yang berkategori tinggi dari siklus I adalah $60 \%$ atau 12 siswa dan pada kategori sedang sebesar $40 \%$ atau 8 siswa. 2). Hasil belajar siswa sebelum tindakan hanya mencapai $30 \%$ yaitu 6 siswa yang tuntas. Setelah tindakan, pada siklus I mengalami peningkatan menjadi 55\% yaitu 11 siswa yang tuntas. Setelah dilakukan siklus II terjadi peningkatan menjadi $95 \%$ yaitu 19 siswa yang tuntas. Berdasarkan hasil penelitian, pembelajaran problem based learning dapat meningkatkan motivasi dan hasil belajar siswa.
\end{abstract}

Kata Kunci: Motivasi belajar, Hasil belajar, Problem Based Learning, Powerpoint

\section{ABSTRACT}

This study aims to determine the increase in motivation and learning outcomes of class X MAN Batang. This research is a Classroom Action Research. The subjects of this study were students of class X MAN Batang. Data collection uses documentation, observation, questionnaire and test techniques. The validity of the data using source triangulation techniques and triangulation techniques. The data analysis technique went through three stages, namely data reduction, data presentation and conclusion drawing. The results of the research conducted are 1). The students' learning motivation in the high category from the first cycle was $60 \%$ or 12 students and in the medium category it was $40 \%$ or 8 students. 2). Student learning outcomes before the action only reached $30 \%$, namely 6 students who completed. After the action, in the first cycle increased to $55 \%$, namely 11 students who completed. After the second cycle, there was an increase to $95 \%$, namely 19 students who completed. Based on the research results, problem-based learning can increase student motivation and learning outcomes.

Keywords: learning motivation, learning outcomes, problem based learning, powerpoint

\section{PENDAHULUAN}

Pendidikan mempunyai peranan yang sangat penting dalam mencerdaskan kehidupan bangsa, oleh sebab itu masing-masing individu yang terlibat dalam pendidikan dituntut untuk ikut serta secara maksimal guna meningkatkan mutu pendidikan tersebut. Pendidikan terdiri dari beberapa komponen, dua diantaranya yaitu pendidik dan peserta didik. Agar proses pembelajaran berhasil, pendidik harus berperan secara aktif, untuk memberi motivasi kepada peserta didik agar aktif belajar dan memberikan pengalaman belajar kepada peserta didik. Guna mendukung tercapainya tujuan pendidikan sesuai yang tercantum dalam UU No. 20 tahun 2003 tentang sistem pendidikan nasional pasal 3 disebutkan tentang tujuan pendidikan yaitu mengembangkan potensi peserta didik agar menjadi manusia yang beriman dan bertakwa kepada Tuhan Yang Maha Esa, berakhlak mulia, sehat, berilmu, cakap, kreatif, mandiri serta menjadi warga negara yang demokratis juga bertanggung jawab.

Hasil belajar adalah proses penentuan tingkat kecakapan penguasaan belajar seseorang dengan cara membandingkannya dengan norma tertentu dalam sistem penilaian yang 
disepakati. Objek hasil belajar diwujudkan dengan perubahan tingkah laku seseorang dalam ranah kognitif, afektif dan psikomotorik. Secara umum, faktor-faktor yang mempengaruhi hasil belajar adalah (1) ada materi atau mata pelajaran yang dipelajari, (2) faktor lingkungan peserta didik, (3) faktor instrumental, (4) keadaan individu peserta didik, dan (5) proses belajar mengajar. Jenis mata pelajaran atau materi yang dipelajari juga turut mempengaruhi proses dan hasil belajar, misalnya belajar tentang pengetahuan yang bersifat konsep berbeda dengan belajar tentang pengetahuan yang bersifat prinsip. (Sudjana, 2009) mengatakan bahwa ada beberapa hal yang mempengaruhi hasil belajar dan kemudian akan mempengaruhi pencapaian belajar. Faktor-faktor tersebut adalah faktor dari dalam dan faktor dari luar. Faktor kemampuan sangat besar sekali pengaruhnya terhadap hasil belajar. Disamping faktor yang dimiliki siswa, juga ada faktor lain yaitu motivasi, minat dan perhatian, sikap dan kebiasaan belajar, ketekunan, sosial ekonomi, faktor fisik dan psikis. Menurut (Muhammad, 2016) Motivasi adalah perubahan tenaga di dalam diri seseorang yang ditandai dengan dorongan yang berasal dari diri seseorang untuk mencapai tujuan. (Sutrisno, 2020) dalam penelitiannya menambahkan bahwa motivasi dan hasil belajar siswa dapat ditingkatkan melalui banyak cari misalnya penggunaan alat peraga, media maupun model bealajar yang disesuaikan dengan kondisi di dalam kelas dan juga siswanya.

Adanya kesenjangan antara harapan dengan kenyataan, maka peneliti memberi solusi atas permasalahan tersebut dengan Model pembelajaran yang dapat melatih siswa untuk berpikir kritis dalam memecahkan masalah yakni dengan model pembelajaran Problem Based Learning. Menurut (Siswono, 2005) Problem Based Learning adalah suatu pendekatan pembelajaran yang dimulai dengan mengajukan masalah dan dilanjutkan dengan menyelesaikan masalah tersebut. Serta menggunakan media powerpoint untuk meningkatkan motivasi dan hasil belajar siswa. Menurut (Anggawirya, 2011) media powerpoint memudahkan kita dalam merancang berbagai bahan presentasi visual yang menakjubkan menggunakan teks, grafis, foto, animasi, video dan kuis dalam penyajian persentasi kepada siswa. Berdasarkan latar belakang masalah, dapat diidentifikasi berbagai masalah yaitu kegiatan belajar mengajat yang membosankan, kurang antusiasnya siswa dalam proses pembelajaran, keterbatasan guru dalam menerapkan model pembelajaran yang menyebabkan motivasi belajar siswa rendah dan hasil belajar di bawah KKM. Dengan penyajian materi ajar Fikih menggunakan media powerpoint diharapkan dapat menarik perhatian siswa sehingga siswa senang dalam mengikuti kegiatan pembelajaran, hasil belajar meningkat dan pembelajaran dapat bersifat dua arah. Berdasarkan uraian diatas, dapat dirumuskan tujuan dari penelitian ini adalah dengan menerapkan model pembelajaran problem based learning dengan media powerpoint untuk meningkatkan motivasi dan hasil belajar siswa kelas X MAN Batang tahun pelajaran 2021/2022

\section{METODE PENELITIAN}

Jenis penelitian ini adalah penelitian tindakan kelas. (PTK) yang dilakukan pada kelas X MAN Batang pada Semester gasal 2021/2022. Penelitian tindakan kelas ini berawal dari permasalahan yang ada dikelas dalam proses pembelajaran, kemudian diangkat menjadi permasalahan yang memerlukan alternatif pemecahan permasalahnnya.

Teknik pengumpulan data yang digunakan adalah observasi, angket, dokumentasi dan angket (moleong, 2016). Dalam penelitian ini, observasi digunakan untuk mengamati aktivitas guru dan peserta didik dalam proses pembelajaran untuk mengevaluasi setiap tindakan dengan instrumen lembar observasi. Angket digunakan untuk mengumpulkan informasi terkait motivasi belajar setelah tindakan. Dokumentasi digunakan untuk memperkuat data setelah observasi dan mengumpulkan informasi terkait data sekolah yaitu profil sekolah, data siswa dan hasil belajar siswa. Tes hasil belajar digunakan untuk mengukur pengetahuan siswa terhadap materi pembelajaran yaitu penyelenggaraan jenazah pada setiap pertemuan.

Teknik análisis data hasil penelitian melalui 3 tahapan (Sugiyono, 2015) yaitu reduksi data, display data dan coclusion drawing/verivication. Dalam penelitian ini juga menggunakan 
validitas data untuk menguji keabsahan data. Validitas data menggunakan triangulasi sumber dan triangulasi teknik. Validitas data ini digunakan untuk menjamin hasil informasi yang akurat dan menjamin validitas data, agar tidak salah dalam pengambilan keputusan. Indikator keberhasilan penelitian ini adalah pencapaian keaktifan siswa dalam setiap aspek, yaitu motivasi belajar 95\% atau 19 siswa dalam kategori tinggi dan tercapainya hasil belajar dengan ketuntasan belajar mencapai $95 \%$ dari 20 atau 19 siswa yang mendapatkan > nilai KKM. Nilai KKM pada Mata Pelajaran Fikih adalah 71.

\section{HASIL DAN PEMBAHASAN}

Berdasarkan kajian data hasil belajar siswa kelas X MAN Batang, salah satu kendala siswa untuk dapat mencapai nilai KKM adalah rendahnya motivasi siswa dalam proses pembelajaran. Motivasi belajar siswa sangat mempengaruhi hasil belajar. Setelah tindakan siklus I diperoleh data 12 siswa / 60\% sedangkan siswa yang belum mencapai ketuntasan belajar sebanyak $45 \%$. Penelitian ini dilaksanakan dalam dua siklus. Siklus I diperoleh data motivasi dan hasil belajar siswa mengalami peningkatan. Meningkatnya motivasi belajar sangat mempengaruhi hasil belajar siswa.

Persentase motivasi belajar siswa yang berkategori tinggi pada siklus I sebesar $60 \%$ atau sebanyak 12 siswa dan siswa pada kategori sedang yaitu $40 \%$ atau sebanyak 8 siswa. Hal tersebut menunjukkan kenaikan yang signifikan. Dengan naiknya motivasi belajar siswa , maka hasil belajar siswa juga mengalami kenaikan yaitu 55\% atau 11 siswa yang mendapatkan nilai di atas KKM.

Siswa antusias dalam mengikuti pembelajaran fikih dengan penggunaan model problem based learning dengan media powerpoint. Penelitian ini dilanjutkan pada siklus II untuk mengatasi kekurangan yang ada pada siklus I. Pada pelaksaan siklus II, penggunaan media lebih simpel dengan menampilkan teks, gambar, video dan animasi sehingga mudah dipahami. Siswa lebih antusias dalam pembelajaran ini, terlihat siswa aktif dalam menyampaikan pendapat atau ide. Proses pembelajaran pada siklus II lebih meningkatkan pemahaman siswa terhadap materi. Peningkatan motivasi belajar siswa ditunjukkan dengan siswa yang kategori tinggi mencapai $75 \%$ atau 15 siswa dan berkategori rendah $25 \%$ atau 5 siswa. Setelah dilakukan evaluasi pada siklus II, persentase jumlah siswa yang tuntas mengalami peningkatan. Sebanyak 1 siswa yang belum mencapai ketuntasan belajar yaitu 5\%, sedangkan 19 siswa atau 95\% telah mencapai nilai KKM yaitu 71 .

\section{Hasil}

Adapun peningkatan motivasi belajar siswa kelas X MAN Batang dari siklus I dan siklus II seperti pada tabel sebagai berikut:

Tabel 1. Persentase motivasi belajar siswa kelas X MAN Batang

\begin{tabular}{|c|c|c|c|c|c|}
\hline \multirow{2}{*}{ Interval Skor } & \multirow{2}{*}{ Kategori } & \multicolumn{2}{|c|}{ Siklus I } & \multicolumn{2}{c|}{ Siklus II } \\
\cline { 3 - 6 } & & Frekuensi & Presentase & Frekuensi & Presentase \\
\hline $0-40$ & Rendah & 0 & 0 & 0 & 0 \\
\hline $41-70$ & Sedang & 8 & 40 & 5 & 25 \\
\hline $71-100$ & Tinggi & 12 & 60 & 15 & 75 \\
\hline
\end{tabular}


Peningkatan motivasi belajar siswa kelas X MAN Batang pada siklus I dan siklus II disajikan dengan grafik sebagai berikut:

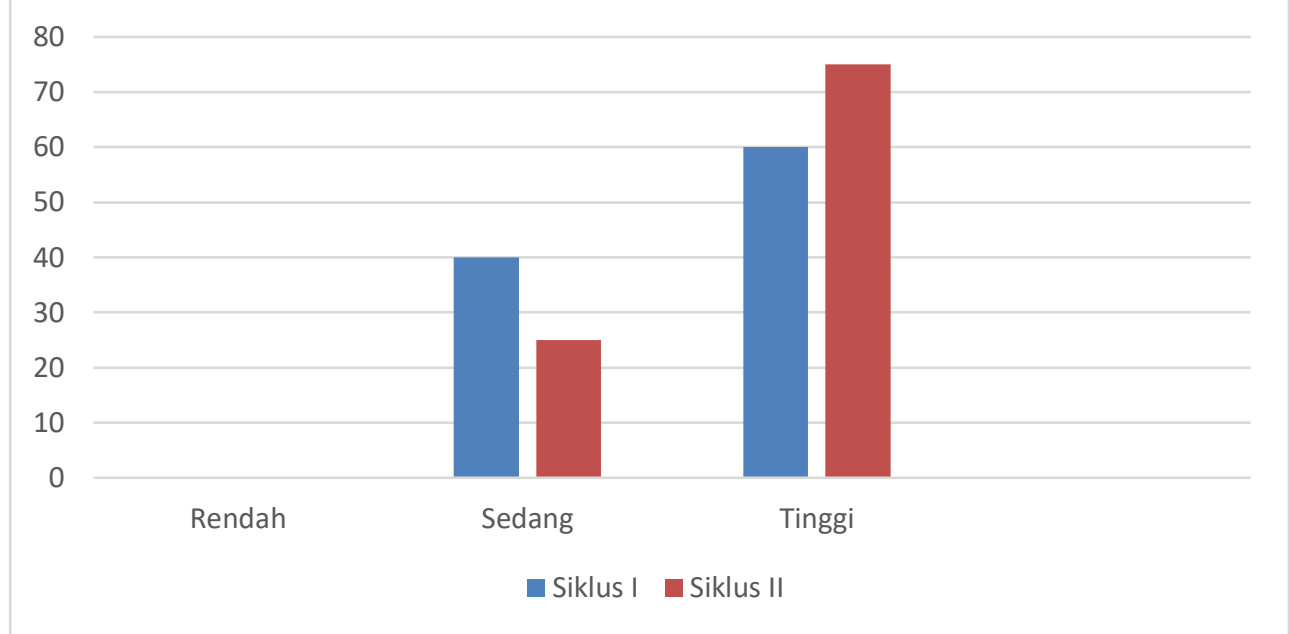

\section{Gambar 1. Motivasi Belajar Siswa}

Adapun peningkatan hasil belajar siswa dari pra siklus sampai siklus II seperti pada tabel berikut:

Tabel 2. Persentase Hasil Belajar Siswa Kelas X MAN Batang

\begin{tabular}{|l|l|l|l|}
\hline $\begin{array}{l}\text { Aspek yang } \\
\text { diamati }\end{array}$ & Para siklus & Siklus I & Siklus II \\
\hline Jumlah Siswa & 6 & 11 & 19 \\
\hline Persentase & $30 \%$ & $55 \%$ & $95 \%$ \\
\hline
\end{tabular}

Peningkatan hasil belajar siswa kelas X MAN Batang pada siklus I dan siklus II disajikan dengan grafik sebagai berikut:

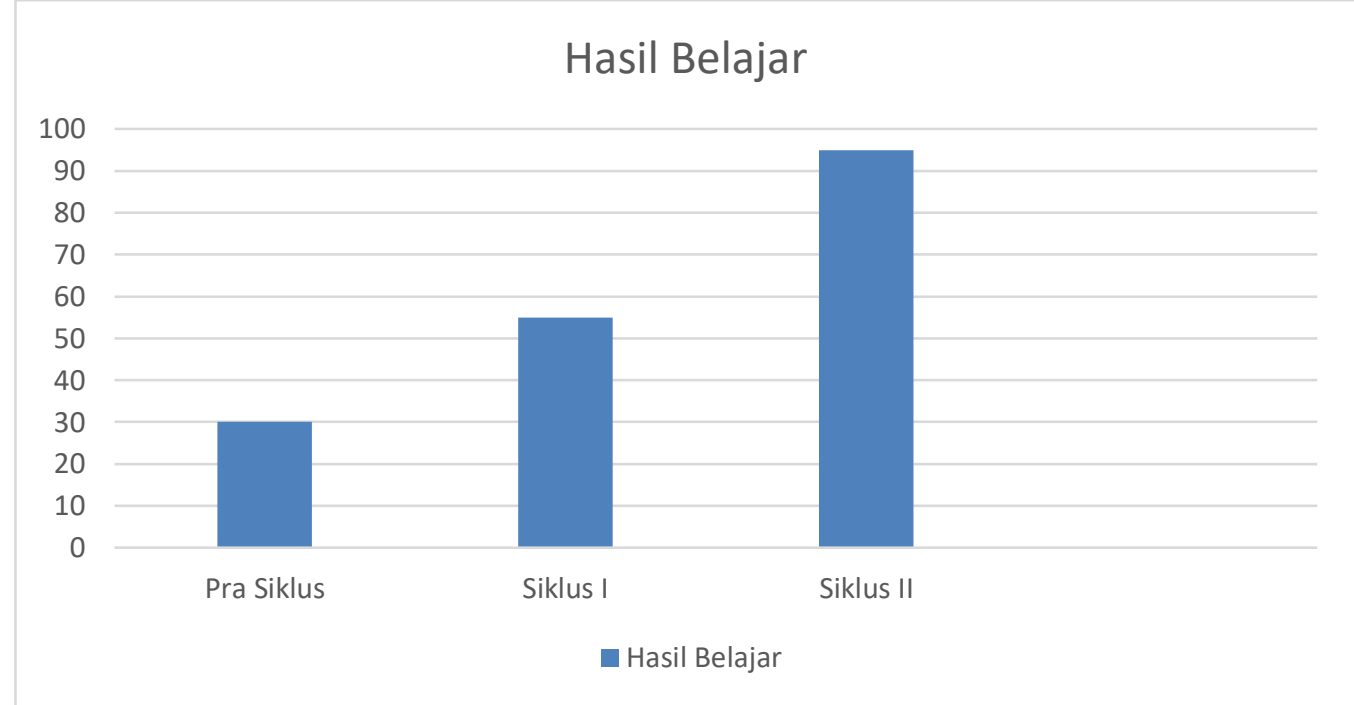

Gambar 2. Hasil Belajar Siswa Kelas X MAN Batang

\section{Pembahasan}

Keaktifan dan hasil belajar siswa sangat ditentukan oleh bagaimana merekan melakukan aktivitas dalam proses pembelajaran. Proses pembelajaran yang monoton tentu tidak akan berdampak bagi keaktifan dan keberhasilan siswa dalam mencapai hasil belajar yang tinggi. Peningkatan hasil belajar siswa bisa ditingkatkan ketika proses pembelajaran yang berlangsung melibatkan siswa dalam berbagai bentuk dan langkah kegiatan. Model pembelajaran problem based learning merupakan salah satu model pembelajaran yang memfasilitasi hal tersebut. 
Tahap-tahap belajar pada problem based learning menunjukkan proses pembelajaran yang bervariasi. Secara umum langkah-langkah tersebut dapat memberikan dampak terhadap peningkatan keaktifan dan hasil belajar siswa. Hasil penelitian ini menunjukkan bahwa guru harus kreatif dan inovatif pada setiap langkah model problem based learning. Guru harus kreatif merancang setiap langkah model problem based learning, hal ini dapat dilihat sebagai berikut:

1. Siklus I

Pada siklus I terdapat empat tahapan yang dilakukan yaitu perencanaan, pelaksanaan, observasi dan refleksi. Pada tahap perencanaan yaitu mempersiapkan perangkat pembelajaran seperti RPP, LKPD dan skenario pembelajaran untuk setiap siklus. Kemudian membuat lembar observasi aktivitas peserta didik dan guru, mempersiapkan media powerpoint serta alat dan bahan pembelajaran. Pada tahapan pelaksanaan, yaitu mengaplikasikan proses pembelajaran sesuai dengan RPP yang diawali dengan kegiatan pendahuluan, kegiatan inti dan kegiatan penutup.

Pada kegiatan pendahuluan, peneliti membuka kegiatan pembelajaran dengan mengucapkan salam, mengabsen peserta didik yang hadir dalam pembelajaran tersebut, menyampaikan kompetensi yang harus dicapai peserta didik setelah pembelajaran berakhir dan melakukan apersepsi dengan menampilkan video powerpoint kemudian memaparkan materi tentang penyelenggaraan jenazah, sehingga peserta didik tertarik dan tertantang untuk belajar Fikih.

Pada kegiatan inti, peneliti memulai materi pembelajaran dengan mengarahkan peserta didik untuk memahami permasalahan tentang penyelenggaraan jenazah melalui media powerpoint kemudian meminta peserta didik untuk mencari solusi cara mengatasi permasalahan tersebut. Melalui diskusi kelompok, peserta didik diberi kesempatan untuk menganalisis hasil pemecahan masalahnya yang diperoleh dari hasil eksperimen. Kemudian peserta didik mempresentasikan hasil kerja kelompoknya didepan. Setelah peserta didik menyampaikan presentasinya, peneliti memberikan penguatan materi. Kegiatan penutup, peneliti memberikan soal pilihan ganda sebanyak 15 butir soal yang terdiri dari 10 butir soal pilihan ganda dan 5 butir soal essay.

2. Siklus II

Peneliti melakukan perbaikan pada penyusunan RPP pada siklus II dengan mengoptimalkan waktu pada pembukaan, alokasi waktu pengolahan data dan presentasi yang dilakukan peserta didik. Selain itu peneliti juga mempersiapkan alat dan bahan untuk praktik dalam penyelenggaraan jenazah agar lebih efektif dan efisien. untuk memahami materi penyelenggaraan jenazah.

Berdasarkan uraian diatas dapat diketahui bahwa dengan menerapkan problem based learning dan penggunaan media powerpoint dapat meningkatkan daya tarik dan minat belajar peserta didik untuk mempelajari materi Fikih. Selain itu juga dapat menjadikan peserta didik lebih fokus dan konsentrasi sehingga memudahkan peserta didik dalam memahami materi yang disampaikan oleh guru dan dapat meningkatkan hasil belajar. Penerapan model problem based learning membuat peserta didik aktif dalam pembelajaran dan termotivasi, karena pada proses pembelajarannya peserta didik dituntut untuk berpikir kreatif dalam menyelesaikan permasalahan yang terdapat dalam kehidupan sehari-hari. Hal ini didukung (Cahyaningsih, 2020) yang mengatakan bahwa penerapan model pembelajaran Project Based Learning dengan menggunakan media pembelajaran Powerpoint dapat meningkatkan aktivitas belajar dan hasil belajar peserta didik kelas V SD Negeri 1 Pasar Banggi Rembang.

Hal ini diperkuat dengan hasil penelitian (Musfiqon, 2012) yang mengatakan bahwa pembelajaran yang menggunakan multimedia telah terbukti lebih efektif dan efisien serta dapat meningkatkan hasil belajar peserta didik. media powerpoint termasuk juga media yang mengandung unsur suara dan gambar yang dapat dilihat. Hal ini memudahkan peserta didik untuk memahami materi yang abstrak menjadi nyata. 


\section{KESIMPULAN}

Berdasarkan hasil penelitian tindakan kelas dapat disimpulkan bahwa penerapan problem based learning dengan media powerpoint dapat meningkatkan motivasi dan hasil belajar siswa kelas X di MAN Batang. Hal itu dibuktikan dengan adanya peningkatan pada setiap siklusnya, yaitu pada proses pembelajaran yang dilakukan pada siklus II jauh lebih baik dibanding siklus I. Secara umum proses pembelajaran pada siklus II kategorinya sangat bagus. Dari data-data tersebut menunjukkan bahwa tindakan yang dilakukan menunjukkan dari pra tindakan siklus I siklus II mengalami peningkatan yang signifikan. Persentase hasil belajar pada siklus II sudah mencapai target bahkan melebihi. Data ini menunjukkan bahwa proses pembelajaran yang dilakukan oleh guru (peneliti) memberikan dampak bagi peningkatan terhadap hasil belajar siswa. Penerapan pembelajaran problem based learning dengan media powerpoint dapat mengatasi permasalahan yang terjadi pada kelas X MAN Batang

\section{DAFTAR PUSTAKA}

Anggawijaya, Erhans. (2011). Microsoft Powerpoint 2010. Jakarta: PT. Ercontara Rajawali.

Cahyaningsih, P., Siswanto J., dan Sukamto. (2020). Keefektifan Model Project Based Learning Berbantu Multimedia Powerpoint Terhadap Hasil Belajar IPA. Jurnal Penelitian dan Pengembangan Pendidikan. Vol. 4 No.1

Moleong, J. (2016). Metodologi Penelitian Kualitatif. Bandung: Remaja Rosdakarya

Muhammad, Maryam. (2016). Pengaruh Motivasi dalam Pembelajaran. Lantanida Journal, Vol.4 No.2

Musfiqon. (2012). Pengembangan Media \& Sumber Pembelajaran. Jakarta: Prestasi Pustaka Raya

Siswono. (2005). Keefektifan Pendekatan Problem Based Learning terhadap Kemampuan Belajar Kreatif Matematik. Semarang: Unnes Journal of Mathematics Education.

Sudjana, Nana. (2009). Penilaian Hasil Proses Belajar Mengajar. Bandung: Remaja Rosdakarya

Sugiyono. (2015). Metode Penelitian Pendidikan. Bandung: Alfabeta

Sutrisno, Tri. (2020). Pengaruh Perhatian Orang Tua terhadap Prestasi Belajar Siswa (Studi kasus di SMK Muhammadiyah Tangerang Selatan). Tangerang: Universitas Pamulang 